\title{
DIEVIETE KĀLĪ RIETUMU KULTŪRĀ - NERELIĢISKIE KONTEKSTI
}

\author{
Madara Vilne \\ Mg. theol., LU Teologiijas fakultātes doktorante
}

Hinduisma panteonā līdzās vīrišķajām dievībām Višnu, Šivam, Ganešam un citiem jau visai sen ${ }^{1}$ plaukst vitāls sieviškso dievību kults, ko vienā vārdā dēvē par šaktismu. ${ }^{2}$ Šaktismā pielūdz visdažādākās sievišķāas dievības gan kā atsevišķas būtnes, gan vienas lielās dievietes manifestācijas. ${ }^{3}$ Šajā kontekstā īpaši izcel̦ama dieviete Kālī, kuras "biogrāfija" ir aizraujoša pat uz raibā hinduisma fona. Saistoša, pirmkārt, ir viņas "karjeras" straujā augšupeja no marginālas citu dievību dusmu izpausmes līdz pat augstākajai dievībai, pašam Brahmanam,

1 Cik tieši sen, īsti nav skaidrs, jo tiek uzskatīts, ka sieviškso dievību pielūgsme iesniedzas jau pirmsāriskajā laikmetā (Indas ielejas civilizācijā), kad, iespējams, pat pastāvējis "matriarhāts", tomēr sievišksās dievības tiek integrētas ortodoksālajā hinduisma praksē, sākot ar apmēram 6. gs. AD - tās plaši aprakstītas purānu literatūrā (tiek uzskatīts, ka tās pat tur dominē), tāpat dieviešu uzplaukums saistāms arī ar tantrisma "slavas gājienu”, kas aizsākas ap šo laiku, utt. "Šāktism," J. Bowker, ed., The Oxford Dictionary of World Religions (Oxford/New York: Oxford University Press, 1997), 841.

2 Reizēm gan nav īsti skaidrs, kas dēvējams par šaktismu, jo tas bieži saplūst un pārklājas ar tantrismu, tomēer, kā norāda pētnieki, šaktisms uzskatāms par patstāvīgu fenomenu. Īsi rezumējot, kā to dara Benojs Gopals Rajs, - šaktisms ir sievišǩ dievību, realitātes sievišķo principu pielūgsme (Benoy Gopal Ray, Gods and Karma in Indian Religions (Santiniketan, West Bengal: Centre of Advanced Study in Philosophy Visva-Bharati, 1973), 35), kamēr tantrisma augstākā dievība var būt arī Šiva vai Višnu. "Tantrism," J. Bowker ed., The Oxford Dictionary of World Religions, op. cit., 949.

3 "Šāktism," ibid., 841. 
dažos tantrisma virzienos. ${ }^{4}$ Visdažādākajā veidā un formā Kālī ir plaši pielūgta mūsdienu hinduisma (un ne tikai) tautas masās un godāta veselos regionos, būdama gan universālā Māte, gan lokāla ciema dievība, arī daudzu gimeņu "mājas dievība".

Otrs ar Kālī saistītais interesantais fenomens ir pašas dievietes pretrunīgais raksturs. Vēsturiski Kālī tikusi attēlota kā baisa figūra, kurai no mutes tek asinis un kura nēsā no galvaskausiem veidotu kaklarotu un nocirstu roku jostu. Vina ir dievību kolektīvo dusmu iemiesojums, kas parādās ekstremālās situācijās, kad pasaule ir apdraudēta un tā jāglābj no dēmoniem. ${ }^{5}$ Tomēr laika gaitā Kālī iegūst arī daudz patīkamākas kvalitātes - drausmais vecenes izskats nereti kḷūst par skaistas sievietes atveidu, ${ }^{6}$ bet līdz ar kḷūšanu par Universālo Māti Kālī tiek godāta kā žēlastīga, tāda, kas rūpējas par saviem pielūdzējiem, ${ }^{7}$ atbrīvojot vai palīdzot dzīves skarbajos brīžos, visbeidzot, dodot dedzīgākajiem pilnīgu atbrīvi no ciešanu pilnās materiālās eksistences ${ }^{8}$ vai vismaz pēcnāves patvērumu savā paradīzē. ${ }^{9}$

19. gadsimtā, Rietumos aizsākoties aktīvākai interesei par Indijas kultūru, Kālī nepaliek nepamanīta - par viņu šausminās Rietumvalstu pētnieki. ${ }^{10}$ Tomēr tas nav uz ilgu laiku līdztekus pieaugošajai interesei par hinduismu vispār, kā arī

${ }^{4}$ David Kinsley, "Freedom from Death in the Worship of Kālī," Numen, Vol. XXVI, Fasc. 3, 189.

5 Ibid., 183, 186.

6 Piemēram, Karpuradi-stotrā. Lina Gupta, "Kali, the Saviour," Religion and Social Transformations, ed. David Herbert (Ashgate, 2001), 21.

7 Šāda tendence novērojama arī Rudra-Šivas kultā, kur sākotnēji vēdiskais dievs Rudra bija destrukcijas dievs, bet, ar lūgšanām pielabināts, tas kḷuva par Šivu (tulkojumā "labestīgais"). Benoy Gopal Ray, Gods and Karma in Indian Religions, op. cit., 29.

8 Sri Swami Sivananda, All about Hinduism (Tehri-Garhwal, Himalayas, India: The Divine Life Society, 1977), 339.

9 David R. Kinsley, Hinduism: a Cultural Perspective (Englewood Cliffs, New Yersey: Prentice-Hall Inc., 1982), 121.

10 Kā izsakās Deivids Kinslijs (Kinsley) - ja mēs neko nezinātu par Kālī popularitāti Indijā, tad viegli noturētu viņu par marginālu parādību, ko pielūdz tikai sabiedrības padibenes. David Kinsley, "Freedom from Death in the Worship of Kālī," Numen, op. cit., 184. Paradokss ir tāds, ka novērojams ir tieši pretējais, tādēl ir interesanti pētīt, kādi faktori nosaka šìs šausminošās dievietes popularitāti gan Indijā, gan sekojoši arī Rietumu pasaulē un Latvijā. 
tieši hindu dieviešu pētniecības uzplaukumam (no 1970. gada) ${ }^{11}$ Kālī arī šeit izvirzās prominentā pozīcijā. To veicina gan ar globalizāciju saistītā kultūru sajaukšanās (autentisku hindu, šai gadījumā Kālī pielūdzēju, kopienu veidošanās dažādās valstīs, piemēram, ASV), gan brīvu interpretāciju iespaidotas dažādas semihinduistiskas grupas, gan tīri komerciālos nolūkos izmantojami "kliedzoši" 12 elementi. Kālī atribūtikā šo aspektu netrūkst, jo, pārstāvot "tumšo" (tāpat arī "erotisko" tantrisma kontekstā), ${ }^{13}$ bieži tradicionāli kristīgajās kultūrās aizliegto vai noklusēto dzīves daḷu, viņa kalpo par savdabīgu leg̣itimizāciju, pat sakralizāciju šīm dzīves sfērām.

Saistībā ar Kālī var uzplaukt tantriskā seksa terapija rietumniekiem, kas noguruši no noplicinātām attiecībām, ${ }^{14}$ tāpat viņa kḷūst arī par vienu no feminisma simboliem gan pašā Indijā, gan, šķiet, vēl vairāk Rietumos, iemiesojot stiprās sievietes arhetipu. ${ }^{15}$ Tradicionāli uz patriarhālo kristīgo religíio-

11 Tas izskaidrojams ar finansējuma pieaugumu Dienvidāzijas studijām, feminisma aktivitātei, kā arī lokāliem lauka pētījumiem, kur dominē dievietes. Rachel Fell McDermott, "Goddess Worship: the Hindu Goddess," Encyclopedia of Religion, ed. Lindsay Jones, Vol. 6, 2nd ed. (USA: Thompson \& Gale, 2005), 3607.

12 Kālī kontekstā šis vārds lietojams gandrīz tiešā nozīmē, jo vinas atvērtā mute ar izkārto mēli esot kalpojusi kā iedvesmas avots arī The Rolling Stones albuma vāka dizainam. Nika Kuchuk, From the Temple to the Witch's Coven: Journeying West with Kali Ma, fierce Goddess of Transformation. A Study of Contemporary Kali Worship in North America: Syncreticism, Sacred Relationships and the Gendered Divine: A Thesis Submitted in partial fulfillment of the Requirements for the Degree of Master of Arts of Religious Studies under the Supervision of Dr. Anne Walley (Ottawa, Canada, 2013), 12.

13 Šeit var piebilst, ka vairākas Rietumu pornozvaigznes esot pieņēmušas vārdu Kālī. Wendy Doniger, The Hindus: An Alternative History (Oxford University Press, 2009), 644.

14 Šajā kontekstā mūsdienās parādījusies t. s. tumšā tantra (dark tantra), kura apvieno BDSM prakses ar dievietes Kālī "rituāliem", piemēram, "Dark Tantra - Tantra Bondage - Goddess Kali Retreat", April 8, 2017, http://theconnectionuniversity.com (skatits 22.05.2018.)

15 Rachel Fell McDermott, "Goddess Worship: the Hindu Goddess," op. cit., 3609. Šis jautājums gan ir pretrunīgs, jo nereti indiešu feministes izvairās dievietes izmantot šādā veidā, saskatot tieši patriarhālos aizspriedumus (Rachel Fell McDermott, "Durgā and Kālī," in Encyclopedia of Women and World Religion, ed. S. Young, Vol. 1. (USA, New York: McMillan Reference, 1999), 275), kā arī tiek norādīts, ka tieši sava kareivīguma dēl Kālī nav nekā kopīga ar sievišksību un sievietēm (Viktors Ivbulis, Siva izdejo un sagrauj pasauli: ievads tradicionālajā hindu 
zitāti balstītajām Rietumu kultūrām šāds Dieva sievišķ̧o aspektu izcēlums ir ne vien eksotisks, bet arī tradīcijām bagāts precedents, lai par šo tēmu runātu. Šajā iespaidā mūsdienās veidojas daudzas dievieti, tostarp arī Kālī, pielūdzošas kustības. ${ }^{16}$

Straujā hinduisma kultūras eksplozija Rietumos izraisa daudz jautājumu - vai tradicionāli Indijai piederīgos reliǵiskos simbolus drīkst brīvi pārņemt un interpretēt, kā ienāk prātā? Varbūt tie ir radušies sava laika kultūras un sociālajā klimatā un vispār nav adaptējami? Vai varbūt hinduismā sastopamā interpretācija ir tikai viena no versijām, kā saprast šīs "universālās reālijas"? Šis ir nopietnu debašu lauks, kurā var dzirdēt arī sarūgtinātas balsis, kas uzskata, ka globalizācija nav nekas cits kā koloniālisma atgriešanās, kad Rietumos pārveidotie hindu simboli atgriežas "mājās" kā dominējošie, padarot oriğinālās versijas par marginālām. ${ }^{17}$ Šajā kontekstā gan būtiski apzināties, ka hinduisms visnotalı nav kaut kas viengabalains, - tas ir izgājis dažādas transformācijas fāzes gan vēsturiskā, gan géeogrāfiskā aspektā, t. i., grūti ir definēt, kas īsti ir un kas nav autentisks, jo pašā hinduismā eksistē visdažādākās pretrunīgākās variācijas.

Šajā rakstā vēlos sīkāk aplūkot, kādā veidā Kālī tiek adaptēta Rietumu kultūras vidē, koncentrējoties galvenokārt uz nereligiskajiem kontekstiem (populārajā kultūrā, psihologijijā, feminismā un nedaudz neopagānismā), tātad neapskatot Kālī hindu diasporas Rietumos, kā arī New Age jeb vesternizētā hinduisma ietvaros, jo tas būtu pārāk plaši ši raksta apjomam. Piebildīšu tikai, ka arī diasporas hinduismā, kas cenšas saglabāt "autentiskumu" jeb cieši sekot Indijas paraugam, Kālī

domā (Rīga: Zinātne, 2003), 285. lpp.), bet sīkāk to aplūkošu feminisma sadaḷā pie Kālī adaptācijas Rietumos.

16 Viens piemērs ir Nikas Kučukas (Nika Kuchuk) pētītā Šakan (Sha'can) kustība Kalifornijā, kas apvieno šaktismu (īpaši Kālī pielūgsmi) un vikānismu (Nika Kuchuk, From the Temple to the Witch's Coven: Journeying West with Kali Ma, fierce Goddess of Transformation, op. cit., 14), tā arī tiks apskatīta darba otrajā nodal̦ā.

17 Šādu uzskatu pauž, piemēram, Sukalpa Batačardže (Bhattacharjee). Sukalpa Bhattacharjee, "Kali in the World Encountering Kali in the Margins, at the Centre, in the West" by Rachell Fell McDermott and Jeffrey Kirpal, Economic and Political Weekly 40.40 (Oct. 1-7, 2005): 4321-4325. Arī šim fenomenam detalizētāk pieskaršos nodaḷā "Kālī populārajā kultūrā". 
pielūgsme iegūst jaunus aspektus, ${ }^{18}$ bet New Age vidē sastopama liela interpretāciju daudzveidība, lielākoties dievieti Kālī uzlūkojot kā cilvēka iekšèjā potenciāla atraisītāju, kas palīdz ìstenot slēptākās vēlmes un sakārtot dzīvi. ${ }^{19}$ Vārdu sakot, notiek process, ko varētu nosaukt par reliǵijas psihologiizāciju, hindu dievības, tostarp Kālī, kḷūst par iekšējiem spēkiem pašā cilvēkā, lielā mērā zaudējot savu ontolog̣isko statusu. Cilvēki vairs nekalpo dievībām, jo dievības kalpo cilvēkiem viņu individualizēto, praktisko vajadzību apmierināšanai, turklāt novērojams ideju eklektisms, nešksirojot to avotu.

\section{Kālī populārajā kultūrā}

Dievietes Kālī atpazīstamība galvenokārt saistāma tieši ar populāro kultūru. Kā izsakās kādas neopagānu vietnes autors, Kālī ir viszināmākais hinduisma tēls tiem cilvēkiem, kas vispār neko nezina par šo reliğiju. ${ }^{20}$ Šeit, visticamāk, "vainojams" Kālī veidola eksotiskums, seksuālā un agresīvā konotācija, kā arī dievietes pretrunīgā daba, kas l̦auj Kālī simboliku izmantot visdažādākajos veidos.

Tieši Kālī izmantojums populārajā kultūrā ir tas, kas visvairāk saniknojis hindu ticīgos. Piemēram, indiešu profesore Sukalpa Batačardže (Sukalpa Bhattacharjee) savā recenzijā

18 Piemēram, Laguna Beach Kali Mandir dibinātāja ir austriešu izcelsmes sieviete Elizabete Uša (Usha) Hārdinga, kas arī "apmācīta veikt rituālus”, - būtiska atkāpe no indiskās tradīcijas. Tāpat templis uzņem dažādus ticīgos, veidojot tiltu starp Rietumiem un Austrumiem. Turklāt Kālī hinduismā pazīstama kā "plēsīgā" dieviete, t. i., viņai, atšksirībā no daudzām citām hindu dievībām, tiek ziedoti arī asinsupuri galvenokārt kazu veidolā, bet Rietumos asinsupurēšanas netiek veiktas. Līdzīgi novērojamas arī citas atkāpes no tā, kā tiek uzlūkota dieviete u. c.

19 Piemēram, kādā Ideal Mantra mājaslapā zem lozunga "Atrodi savas dzīves risinājumus caur Maha Kali Mantru" teikts: "Maha Kālī Mantra piepilda tevi ar spēku un drosmi, kas padara tevi daudz spēcīgāku par problēmām, ar ko tu sastopies, un palīdz tās ātri atrisināt. [..] Tā dod tev energ̣iju kā Bourn vita pienā un padara tavu dzīvi daudz mirdzošāku. Tu attīsti daudz pozitīvāku attieksmi pret dzīvi un tā kḷūsti priecīgāks ar katru dienu [..] Maha Kālī Mantra palīdz tev sasniegt neiespējamo jebko no labas finansiālās pozīcijas un visu parādu nolīdzināšanas līdz mūža mīlestības atrašanai [..]" "Find Your Life Solutions Through The Maha Kali Mantra," https://www.idealmantra.com (skatīts 10.05.2018.)

20 Jason Pitzl-Waters, "The Pop-Culture Kali of America," June 4, 2010, The Wild Hunt: Modern Pagan News \& Commentary, http://wildhunt.org (skatīts 10.04.2018.) 
par dievietei Kālī veltītu grāmatu l̦oti asi kritizē Rietumu kultūru un tās Kālī interpretāciju. Viña uzskata, ka līdz ar globalizāciju tiek atjaunotas kolonizatora-kolonizētā attiecības, kur Rietumi rada "surogātKālī", ${ }^{21}$ kas dominē pār savu orig̣inālu (padarot to par "simulakru"). ${ }^{22}$ Viņa to dēvē par "protēžu Kālī", "vienu fetišu starp citiem", ${ }^{23}$ kas apmierina Rietumu kultūras fantāzijas, bailes, ilgas un citas vajadzības, ${ }^{24} \mathrm{Ka} l \bar{l}$ revitalizē Rietumu kultūras noplicinātos aspektus. ${ }^{25}$ Tiek apspiesta Kālī "citādība", un Rietumu postmodernisma logikas garā (dēvējot to par "starpkultūru sapratni") tiek piedāvātas standartizētas interpretācijas. ${ }^{26}$

Var piekrist, ka ir klaji komerciālas epizodes, kā, piemēram, 2010. gada notikums, kur kāda firma Accoutrements bija sākusi ražot "Kālī sūkājamās konfektes", ${ }^{27}$ - tas patiešām uzskatāms par izsmieklu vai absolūtu neizpratni par Kālī religisiskajiem aspektiem. ${ }^{28}$ Tāpat Kālī simbolika izmantota pusdienu kastīšu rotāšanai, t-kreklu apdrukai un pat apakšvel̦as reklamēšanai. ${ }^{29}$ No otras puses, arī Kālī "dzimtajā" Bengālē, kā norāda žurnāliste Šoma A. Čaterdži (Shoma A. Chatterji), dieviete rotā

${ }_{21}$ “Tas, kas ir ironiski [..] noteiktas centrēšanās politika, kas stāv iepretī tās sākotnējai kulturālajai lokācijai. Tāda konfigurēta Kālī rada simulakru [..], "peldoša norāde" (floating signifier), "neīsts cits" (false other)." Bhattacharjee, "Kali in the World," op. cit., 4321.

22 "Satikšanās metafora pilnīgi neiekḷauj slēpto Rietumu Kālī tēla dominanci, kas padara kulturālo Austrumu Kālī par simulakru.” Ibid., 4324.

23 Ibid., 4323.

24 Ibid., 4322.

25 Šeit autore acīmredzot, būdama reliǵiski noskaņota, uzskata, ka "Kālī mārketizēšanā ir kas vairāk par sensuālo un vizuālo un tam ir metafizisks komponents, kas generē kulturālu vitalitāti, pārvarot patriarhālo Rietumu trūkumus". Ibid., 4324.

26 Ibid., 4321.

${ }^{27}$ Reklāmas sauklī teikts: "Kālī ir hindu dieviete, kas reprezentē nāvi, iznīcību, laiku un pārmainas. Un kāds ēdiens nāk prātā, kad tu domā par nāvi, destrukciju, laiku un pārmaiņām? Karijs! Š̄s eksotiskās garšvielu konfektes ir lieliskas pašas par sevi vai kā piedeva basmati rīsiem un ķiploku naan. [..]" "Curry Flavour Kali Mints," https://candyhero.com/ (skatits 17.04.2018.)

${ }_{28}$ Internetā bija atrodams arī hindu ticīgā lūgums parakstīt petīciju par šo konfekšu aizliegšanu. Kunal Ghose, "Stop sale of "Curry flavour Kali Mints"," https://www.change.org (skatīts 04.04.2018.). Izskatās, ka iniciatīva bija veiksmīga, jo ierakstu komentējusi pati ražojošā firma un šobrīd šo konfekšu pārdošanā, šksiet, vairs nav.

29 https://www.cafepress.com utt. (skatīts 04.04.2018.) 
visu iespējamo - no autobusu aizmugurēm un pieturām līdz tām pašām pusdienu kastītēm, kafejnīcām un taksometriem. ${ }^{30}$ Protams, varētu teikt, ka šeit dzīvo tikai īsteni dievietes pielūdzēji, tomēr Kālī simbolikas izmantojumu tik triviālos veidos, iespējams, arī varētu uzskatīt par sekularizēšanās tendenci. ${ }^{31}$

Tomēr jāteic, ka Kālī tēli populārajā kultūrā ne vienmēr ir tik viennozīmīgi vērtējami. Dažkārt tiem ir arī izglītojoša nozīme un to autori, visticamāk, nav vēlējušies aizskart hindu ticīgos. ${ }^{32}$ Tāds piemērs, iespējams, ir seriāls "Ksena - kareivīgā princese" (Xena: the Warrior Princess). Tā galvenā varone ir drošsirdīgā Ksena, kas, glābjot savus draugus no dēmonu karal̦a Indradžeta (Indra-jeet), pārvēršas par dievieti Kālī. Šī epizode izraisījusi asas diskusijas un nosodījumu no hinduistu puses, tomēr, piemēram, Kālī pētniece Nika Kučuka (Nika Kuchuk) uzskata, ka attēlojums bijis samērā autentisks un nebūt ne aizskarošs. ${ }^{33}$

30 "Kālī [..] ir visuresoša uz katra ielas stūra - autorikša aizmugurē, uz katra bengāḷu taksometra panel̦a, veikalos, kas pārdod jebko, no ātrās maltītes līdz kartupel̦iem, gaļai un vistām, pilsētas autobusa aizmugurē utt." Dievietes Kālī simbolika tikusi izmantota arī asiņu donorēšanas akcijā! Shoma A. Chatterji, "The "Culture" of Kali - the Secular Goddess", Oct. 13, 2005, http://ourfrontcover.com (skatīts 04.04.2018.)

31 Čaterdži raksta nosaukums ir "Kālī "kultūra" - sekulārā dieviete", tā kā viņa ir no Kalkutas, tad šādam vērtējumam acīmredzot ir pamats.

32 Kā izsakās Nika Kučuka, "Ceturtās sezonas epizodē Ksena pārvēršas par Kālī, lai uzveiktu dēmonu karali Indra-jeet, tas ir stāsts, kas notiek Ksenas un Gabrielas ceḷojumu laikā Indijā. S̄i epizode, kas radīta, aktīvi iesaistoties indoamerikāṇu politiskajai organizācijai (Indo-American Foundation), atspoguḷo feministisku modeli, redzot Kālī tēlu kā "nikno Dievietes aspektu”. Pats šovs ir ikonisks Ziemel̦amerikas kultūrā, īpaši mīlèts feministu vidē tā spēcīgā un kompleksā sieviešu tēlu atspoguḷojuma dēlı, tādēl Kālī atainojums ir dubultnozīmīgs. Epizodes beigās divi galvenie aktieri un organizācijas prezidents pauda cerību, ka ir attēlojuši Indijas lūgšanas un reliğijas cieņpilnā garā, un Lūsija Lolesa (Lucy Lawless), kas attēlo Ksenu, saka: "ar izpratni nāk tolerance"." Kuchuk, op. cit., 12.

33 "Runājot personiski, es īstenībā uztvēru minēto epizodi ("Ceḷšs", sezona 4:16) kā atsvaidzinoši sensitīvu pret kulturālām un reliǵiskām realitātēm, tās producenti un autori skaidri mēǵina gan izklaidēt, gan izglìtot to audiences - vismaz relatīvi. Vienlaikus tas bija kaut kādā ziņā neparasts (no hindu viedokḷa) cilvēciskas sievietes atainojums (kaut gan viṇa ir varone), kas kḷūst par dievietes avataru. Kaut gan teorētiski uzņemta Indijā senā pagātnē, ir būtiski atcerēties, ka Ksena ir fantāzijas produkts, un tādēḷ varbūt var tikt piel̦auta neliela daḷa mākslinieciskuma, 
Tāpat Rietumos sastopami dažādi Kālī tēla pielietojumi vizuālajā mākslā. ${ }^{34}$ Piemēram, tiek uzskatìts, ka The Rolling Stones albuma vāka dizainu (ar lūpām un mēli) iedvesmojis tieši Kālī tēls. ${ }^{35}$ Lai vai kā ar Kālī simbolikas izmantotāju dievbijību, skaidrs ir tas, ka dieviete kḷuvusi par "kosmopolīti" un šo procesu diez vai var apturēt. Daži pētnieki norāda, ka šāda "klaiņošana" ir hindu dievietes garā, jo arī Indijā tā dažkārt mēdz "pārcel̦ot", turklāt tās simbolika arī pašā Indijas vidē ir plūstoša, iekḷaujot dažādus jaunus un lokālus paveidus. ${ }^{36} \mathrm{Lìd} z$ ar to Kālī izmantojums populārajā (un vispār) kultūrā tiek vērtēts lı̀ti pretrunīgi - no teju nozieguma ${ }^{37}$ līdz normālai, jau pašā hindu dievbijīibā iekodētai parādībai.

\section{Kālī un psihologija}

Vēl viens Kālī adaptācijas lauks ir psiholog̣ija. Būtībā psihologiju Rietumu kontekstā nevar uzskatìt par noškşirtu sfēru,

it īpaši, ja mērķis ir iedrošināt sievietes un radīt zināšanas par citām kultūrām un ticējumiem [..]" Ibid., 111.

${ }^{34}$ Sīkāk to analizē, piemēram, Nika Kučuka. Ibid., 129-140.

${ }_{35}$ Ibid., 12.

${ }_{36}$ "Savdabīgi, ka "klaiņojošās" dievietes tradīcija [..] nav tikai unikāli rietumniecisks, moderns fenomens. Iespējams, Kālī ir tik labi zināma Rietumos tieši tāpēc, ka viñas pašas kultūrā pastāvēja ilgstošas pārceḷošanas tradīcijas. Pat Bengālē Kālī pielūgsmes centrs Kālè no Kalighat patiesībā ir patvērums. Džūna Makdaniela (June McDaniel) uzsver tendenci Kālī tautas (folk) statujām tikt asociētām ar specifiskām vietām, kḷūstot par "celıotājām", kad statuja tiek pārvietota: "aizsargājošā Kālī no Dacca Bangladešā bija Dhakešvari vai Ramna-Kālī [..] (viṇa) tagad ir patvēruma meklētāja kā hinduisti, kas bija spiesti pārcelties [..]”. Rietumbengāle, jau izmitinot neskaitāmas tautas, cilšu un nacionāla mēroga Kālī, viegli pieņēma šo jauno (un vienlaikus ne vairs jauno) Kālī savā vidū.” Ibid., 97-98.

${ }^{37}$ Ne tikai Kālī gadījumā, bet vispār ir skaidrs, ka šādās diskusijās iezīmējas vairākas nometnes, no kurām viena pastāv uz to, ka simboliem ir kulturāla izcelsme, un to, ka tos izmantot patvaḷigi citos kontekstos ir noziegums. Nika Kučuka uzskata, ka šis jautājums drīzāk ir politisks, nevis teologisisks, jo kultūras/tautas, kas jūtas apspiestas, uztver šo tematu ļoti sensitīvi un tas nebūt nav tik viennozīmīgs. İpaši jau tādēḷ, ka ne visi domā, ka religiskie simboli ir kultūrnosacīti, - tos var saskatìt arī kā objektīvu, dievišksu, ikvienam sasniedzamu realitāti. Kučuka norāda, ka šāda interpretācija sastopama arī hinduistu vidē, kur dieviete Kālī tiek uzskatìta par šādu realitāti, - "baltajiem" svētceḷniekiem netiek liegts skats uz dievieti, jo Kālī pati izvēlēsies, kam atklāties un kam ne. Ibid., 149. 
jo skaidrs, ka psihologija ir sava veida jaunā Rietumu domāšanas paradigma un prizma, pat savā ziņā relig̣ijas aizstājēja. Psihologiiski tiek pētīts un skaidrots gandrīz viss - dažkārt runājot par "psiholog̣iskiem aspektiem", bet vēl biežāk, ne mirkli nešauboties, "aizskaidrojot" visu neparasto ar psiholog̣iskām parādībām. Arī Kālī simbolika šajā ziṇā nav nekāds izñēmums.

\section{"Analītiskā nometne"}

Interesi par religiskiem simboliem tradicionāli neizrāda gluži visi psihologijijas novirzieni, bet īpašu aktualitāti tie iegūst tieši t. s. dzīḷu psihologijasas ${ }^{38}$ (galvenokārt analītiskās psiholog̣ijas un psihoanalīzes) kontekstā. Reliğisko simbolu analīzi jau aizsāk šo tradīciju dibinātāji - attiecīgi K. G. Jungs un Z. Freids, vēlākie sekotāji gan ievieš savas korekcijas, tomēr pamatnostādnes, šksiet, paliek nemainīgas. Jungs un jungieši runā par mūžīgiem arhetipiem, kas darbojas kolektīvā līmenī caur individuālu apziņu. Kālī pats Jungs skaidro kā "tumšās mātes arhetipu", asociējot to ar pirmatnējo, dzīvniecisko mātes tēlu, kas var būt arī šausminošs. Kā piemēru viņš min cūku, kas spēj apēst savus mazuḷus. ${ }^{39}$

Tāpat Jungs uzskata, ka šādu tēlu parādīšanās ir "bezapziņas kompensatorā darbība" - jo apziņā sievietes veidols kḷūst gaišāks un labestīgāks, jo bezapziņa to kompensē ar šausminošākiem tēliem. ${ }^{40}$ Viņaprāt, Austrumu cilvēkam ir vieglāk, jo tas samierina bezapziņas spēkus ar kulta prakses palīdzību (tātad Kālī/Durgas pielūgsmi), bet Rietumu cilvēkiem neatliek nekas cits, kā šos aspektus integrēt savā apzinātajā personībā. ${ }^{41} \mathrm{Ka}$ jau minēju, jungieši dažkārt "iet savu ceḷu", tādēḷ, piemēram,

38 "Dzīḷu psiholog̣ija ir Šveices psihologa un psihiatra Eižena Bleilera [..] ieviests jēdziens, kas tiek izmantots kā “apziņas psihologijas” pretstats. Sākotnēji šis jēdziens bija saistīts ar Freida psihoanalīzi, taču pakāpeniski to attiecināja arī uz analītisko (komplekso) psiholog̣iju, individuālpsiholog̣iju, neoanalīzi un citām ar psihoanalīzi saistītām skolām vai virzieniem." I. Šuvajevs, "Junga lietoto pamatjēdzienu skaidrojumi," K. G. Jungs, Psihologiskie tipi, tulk. I. Šuvajevs un R. Tauriņš (Rīga: Zvaigzne ABC, 1996), 228. lpp.

39 Carl Gustav Jung, Visions: Notes of the Seminar Given in 1930-1934, ed. Claire Douglas, Vol. 1 (Princeton University Press, 1997), 957-958.

40 Ibid., 950.

${ }^{41}$ Ibid., 957. 
Ronalds Karens (Curran) uzskata, ka Kālī nevajag aplūkot kā sieviškzu tēlu (viňš šādu tendenci asociē ar negatīvu mātes kompleksu patriarhālajās kultūrās). Kālī simbolismā viņš saskata individuācijas procesa risku - ego bailes tikt "uroboriskās bezapziņas" aprītam. ${ }^{42}$

Kopumā jungiešu nometnē vērojama tendence dievieti Kālī uzlūkot kā "ēnas arhetipu" ${ }^{43}$ un izmantot to vardarbības traumu dziedināšanā ${ }^{44}$ piemēram, tas pats Karens apraksta situāciju, kur kādai meitenei izdevies atrisināt destruktīvās attiecības ar māti, “dejojot ar Kālī” jeb apzinoties sevī "tumšā feminīnā" arhetipa spēku. ${ }^{45}$ Arī analītiķis Ašoks Bedi (Ashok Bedi) izmanto Kālī tēlu, strādājot ar traumētiem pacientiem. Viņš saskata Kālī kā "psihes paradoksu”, kā arhetipu, kas tiek aktivizēts krīzes situācijā, kas "amputē dvēseles tumsu un dod vietu gaismai [..] iznīcina personības nepilnības un rada vietu jaunas apziņas dzimšanai [..]”, būdama kā starpniece "mūsu attiecībās ar transpersonālo Patību". Bedi arī saskata Kālī simbolisko krāsu atbilstību Junga alk̦īmiskajām nostādnēm, apzīmējot psihiskās transformācijas stadijas: "Kālī trīs acis reprezentē pagātni, tagadni un nākotni. Viņas baltie zobi simbolizē albedo (baltumu) vai dvēseles tīrību, viņas sarkanā mēle - rubedo (sarkanumu) vai dzīves alkas [..] viņa tur nogrieztu galvu, kas simbolizē mūsu ēnas upurēšanu [..] viņa ir

${ }_{42}$ Ronald T. Curran, "Kali, Individuation, and the Primordial Unconscious," Psychological Perspectives 48, 2005, 177. Šeit gan jāpiebilst, ka purāniskā, tantriskā un tautas dievbijības Kālī tēli ir atšksirīgi, tādēḷ arī varētu runāt par dažādiem arhetipiem.

43 “Ēna ir visas negatīvās, nepatīkamās, izstumtās īpašības un rakstura iezīmes, kas pastāv neapzināti, traucē paštapšanu un cilvēkā nereti grūti atšškiramas no dzīvnieciskā [..] Ēna ir morāles problēma, pirmais solis (tikšanās ar ēnu - drosmīguma pārbaude) cẹ̦ā uz paštapšanu [..] Ja ēna netiek ñemta vērā vai tiek radikāli noraidìta, var rasties smagas psihiskās komplikācijas [..] Jungs izšķir individuālo ēnu un kolektīvo (laikmeta, tautas, grupas u. tml.) ēnu." I. Šuvajevs, "Junga lietoto pamatjēdzienu skaidrojumi," op. cit., 229. lpp.

${ }_{44}$ Kuchuk, op. cit., 109.

45 Meitene bija cietusi no vardarbīga "mātes kompleksa", un, dejojot ar Kālī, viṇa sevī apzinājās un integrēja šo tumšo patību, atgūstot savu seksualitāti un pašapziṇu. "Galu galā viñai bija jādejo ar "Kālı̄", lai konfrontētu, iekḷautu un tiktu arhetipālās feminīnās ēnas transformēta." Curran, "Kali, Individuation, and the Primordial Unconscious," op. cit., 184. 
nemainīgs, bezgalīgs, sākotnējs spēks, kas darbojas lielajā drāmā, pamodinot Šivu (bezapzināto maskulīno principu) zem savām pēdām." 46

\section{"Psihoanalizzes nometne"}

Z. Freids savukārt galvenokārt pazīstams kā religijijas noliedzējs un kritiķis, kas izskaidro religiskus fenomenus ar agrīniem bērnības pārdzīvojumiem. Kaut gan daudzi vēlākie psihoanalītiķi pauduši pozitīvāku attieksmi pret reliǵiju, ${ }^{47}$ psihoanalīzes "nometne" ir slavena ar "Edipa kompleksa" hipotēzi un no tās izrietošajiem elementiem. Tā, piemēram, klīniskais psihologs Ramans Kapurs publicējis rakstu "Kālī: indiešu destrukcijas dieviete un kastrācijas impulsu pārvaldība grupās”, acīmredzami lietojot psihoanalīzes atziņas. Viņaprāt, Kālī mitologíja simbolizē sievietes destruktīvo "peņa skaudību", kas it īpaši izpaužas sieviešu kolektīvos, ko vada vīrieši ${ }^{48}$

${ }_{46}$ Kuchuk, op. cit., 173. Es gan šādām interpretācijām nepiekristu, jo Šiva netiek pamodināts, bet gan tikai tēlo guḷošu, jo vēlas apstādināt Kālī neprātu, kā arī ìsti nesaprotu, kā Kālī vienlaikus var būt gan tumšā, sievišķā ēna, gan arī viedais, transformējošais princips, kas nogalina ēnu. Domāju, ka te ir pretruna, jo Kālī ir nevis kāda dēmone, bet gan dieviškss spēks, tādēḷ nedomāju, ka viņa pārstāv ēnu.

${ }_{47}$ Kellija Anna Rāba (Kelley Ann Raab), analizējot Ramakrišnas fenomenu, atsaucas uz vēlākiem psihoanalītiksiem, kam jau ir pozitīvāka attieksme pret religiju. Kelley A. Raab, "Is There Anything Transcendent about Transcendence? A Philosophical and Psychological Study of Sri Ramakrishna," op. cit., 324-325.

48 Šeit arī jāpiebilst, ka Kapurs izmanto tieši tādu Durgas mīta versiju, ko feministes uzskatītu par "patriarhālu izkroplsojumu” (skat. tālāk par feminismu). Tajā dievi liek Durgai uzveikt dēmonu Mahišasuru, nepasakot, ka to viņa var izdarīt tikai kaila. Durga uzveic dēmonu, bet ir saniknota par pazemojumu un atriebjas dieviem. Pat ja šis mìts būtu autentisks (hinduisma literatūrā un tautas ticējumos sastopamas visdažādākās mītu versijas), tad skaidrs, ka vīrišksie dievi tik tiešām nostāda Durgu pazemojošā situācijā un viņas dusmas būtu tikai normāla reakcija, kas par destruktīvu uzskatāma tikai konservatīvi patriarhālos kontekstos, kur sievietei vienmēr jābūt paklausīgai, pat ja viņai tiek darīts pāri. Savdabīgā kārtā līdz ar to Kapurs runā par "peña skaudību”, kas îstenībā ir sacelšanās pret pazemojumu, kur īstā problēma tad drīzāk (ja vispār!) būtu "dzemdes skaudība" jeb vīriškso dievu vēlme pazemot Durgu, kas ir spēcīgāka par viņiem. Katrā ziṇā raksts nodod autora paša personiskās problēmas ( $k \bar{a}$ arī vispārēju vīriešu un sieviešu attiecību spriedzi), kas tiek projicētas uz religisiskajiem tēliem un, manuprāt, tas ir gan nekompetenti, gan sekli, gan nepatiesi. 
Kopsummā gan raksts neatstāj iespaidu par kompetentām zināšanām reliǵijā un ilustrē, cik virspusēji psihologiija reizēm spēj izmantot religiskos simbolus, izraujot atsevišķus aspektus no kopējā konteksta, lai pakḷautu savai ideologiskajai programmai.

Interpretējot Kālī psihoanalītiski, sastopamas arī vēl negatīvāki redzējumi - Kālī var uzskatīt arī par brutāliem vardarbības impulsiem cilvēka psihē. Tā, piemēram, indiešu izcelsmes psihoanalītiķis Sudhi Kakars (Sudhi Kakar), rakstot par militārajiem konfliktiem starp hinduistiem un musulmaņiem Indijā, lieto metaforu "Kālī laiks" (the time of $K \bar{a} l \bar{\imath}){ }^{49}$ Ar to viņš domā izmainītu apziņas stāvokli, kas iestājas bruņotu nesaskaņu laikā: "Tās ir ne tikai šausmu un apdraudējuma sajūtas, bet arī pacēlums, ko izraisa individuālo robežu transcendence, sajūtas par piederību un tuvību būtībai, kas ir pāri paša patībai. [..] Gan cēlonis, gan sekas, lai pamatotu šādu identitāti, ir baumas - vienas no vecmātēm, kas dzemdina Kālı,${ }^{50} \mathrm{kad}$ cilvēki sāk justies bezpalīdzīgi un pārbijušies (bet arī maniakāli pacilāti). [..] spēcīgās bažas, kas pavada Kālī dzimšanu, var aizvest daudzus cilvēkus prom no "zināšanas" uz "nezināšanu" [..., kur viņi vairs neatminas, kas padara tos nemierīgus, kaut gan viņi zina, ka ir stresa situācijā." ${ }_{51}$

Viņš Kālī saista (pretstatā Durgai) ar "slikto māti": "Tā (Durga) ir "labā" māte, dižās mātes-dievietes, skaistās Durgas, mirdzošā seja, kas labvēlīgi noskaņota pret zīdaini [..] Bet, kad māte ir neempātiska, nervoza vai noraidoša, parādās šausminošās, tumšās Kālī - dievietes, kas mums jāciena, lai viña mūs neiznīcinātu, - panti. Kālī padzil̦ina zīdaiņa neuzticēšanos pasaulei [..] Kad komunālā identitāte ${ }^{52}$ pārņem cilvēku, tās nosliece uz vardarbību un vajāšanas mānija izlaužas cauri indivīda “drošības fonam”. Uzticamā mātišksā klātbūtne izgaist, un viss, kas ir svešs iekšpusē un ārpusē, saplūst kopā vienā projekcijā.

${ }_{49}$ "Kāli laiks ir sācies no baumu satura, kas cirkulē starp abām komūnām. [..] ka lieli ieroču uzkrājumi, skābes un citi materiāli [...] tika turēti mošeju pagrabos.” Sudhi Kakar, "The Time of Kali: Violence between Religious Groups in India,” in Social Research, 67:3 (2000), 888.

50 Šeit un turpmāk mans izcēlums. (M. V.)

51 Sudhi Kakar, "The Time of Kali: Violence between Religious Groups in India," in Social Research, 67:3 (2000), 888-889.

${ }^{52}$ Kakara lietots termins, lai aprakstītu fenomenu, kad cilvēks zaudē savu personīgo identitāti grupas identitātes labā. Ibid., 885 u. c. 
Šādās situācijās projekcija ir ne tikai mēǵinājums atbrīvot prātu no destruktīviem elementiem, bet arī piešķir pasaulei, pat ja šausminošu, tomēr pazīstamu formu." ${ }_{53}$ Vārdu sakot, atsaucoties uz Eriksonu, kurš runā par fundamentālo paḷāvības sajūtu, ko zīdainim iedod labvēlīgas attiecības ar māti, Kakars min, ka sastapšanās ar Kālī jeb "slikto māti" rada sākotnēju neuzticēšanās impulsu, kas vēlāk izpaužas kā tendence uz aklu vardarbību.

Principā tas, ko viñš apraksta kā "Kālī dzimšanu” vai "Kālī laiku”, ir "pūḷa neprāts", "masu psihoze”, kas parādās ekstremālās situācijās, vispārējam apziņas līmenim nokrītot līdz pašām zemākajām izdzīvošanas pakāpēm. ${ }^{54}$ Es domāju, ka š̄ ir pati primitīvākā Kālī interpretācija, kas pilnīgi nesaskan ar relig̣iskajā kontekstā novēroto, jo diez vai kāds būtu gatavs pielūgt tik galēji aklu, destruktīvu spēku. Protams, Kakars arī skaidri pasaka - tā ir nevis pielūgsme, bet gan "pielabināšanās", lai šis spēks mūs neiznīcinātu, tomēr domāju, ka bezapzinātiem vardarbības impulsiem pielabināties nav iespējams, turklāt tas absolūti nesaskan ar izplatīto bhakti hinduismu, kur dieviete tiek uzskatīta tieši par mīlošu, nevis iznīcinošu māti. Dieviete ir apzinātais spēks, kas stājas pretī dēmoniem un aizsargā savus ticīgos. Manuprāt, Kakars, pats būdams

53 Sudhi Kakar, "The Time of Kali: Violence between Religious Groups in India," Social Research, 67:3 (2000), 889-890.

${ }_{54}$ Šo fenomenu, škikiet, pirmais aprakstījis Gustavs Lebons. Grāmatā "Pūlis" (The Crowd) viņš aplūko fenomenu, ka, sanākot grupā, cilvēku uzvedība krasi mainās salīdzinājumā ar to, ko tie paustu individuālā kārtā. Lebons runā nevis par nejaušām grupām, bet tādām, kam ir kopīgs mērk̦is. Jo vairāk faktoru, kas vieno kādu grupu, jo lielāka iespējamība, ka tā reagèès kā vienots kermenis (body) un izpaudīs fenomenu, kas interesēja Lebonu, - indivīda transformāciju kolektīva labā. Vinšs apgalvo, ka īpašos apstākḷos (un tikai tajos) cilvēku aglomerāts uzrāda jaunas īpatnības, kas l̦oti atšksiras no individuālajām. Noskaņojumi un idejas iegūst vienu virzienu, un indivīdu apzinātā personība izgaist. Vinaprāt, rodas kolektīvais prāts - organizēts pūlis vai psihologisks pūlis, "būtne" (single being). Šo konceptu pārņem arī citi psihologi, tostarp Freids un Jungs, pēdējam uzlūkojot to galēji pesimistiski: "jebkuras pilnībā apbrīnojamu personu kompānijas moralitāte un intelig̀ence ir kā neveiklam (smagnējam), primitīvam un nežēlīgam dzīvniekam. Jo lielāka sapulce, jo neizbēgamāka ir tās amoralitāte un akls stulbums". Lebonam gan pašam bija arī pozitīvāks redzējums par "pūḷa psiholog̣iju” - tas varēja būt arī eksaltēts un augstu mērksu iedvesmots. N. Caputi, A Guide to the Unconscious (Birmingham, Alabama: Religious Education Press, 1984), 89-93. 
indietis, tomēr pieḷauj l̦oti klasisku pārpratumu, dievieti pašu padarot par dēmoni. ${ }^{55}$

\section{Citi konteksti}

Necenšoties aplūkot visus Kālī psihologiiskos interpretācijas modeļus (kas droši vien būtu neiespējami), vēlos akcentēt vēl tikai vienu - individuālu psiholoǵisku pieeju dievietei. Mūsdienu individuālistiskajā laikmetā cilvēki arvien biežāk nodarbojas gan ar personalizētām religijas, gan psiholoǵijas, gan pašterapijas formām, tādēl l̦audis dažkārt spontāni nonāk pie Kālī tēla un lieto to savu personisko dzīves situāciju risināšanā. Tā, piemēram, Sjūzena Kaperna Loida (Susan Caperna Lloyd) rakstā "Atklājot dieviškso izšksīšanā: kā kādas sievietes ziņkārība noveda viņu pie dzil̦as sastapšanās ar Dievieti Kālī, dodot viņai mieru pēc personiska zaudējuma" apraksta savu celojumu pēc vairāku tuvu radinieku pēkšņas nāves. Loida devusies uz Indiju dievietes Kālī svētku laikā. Viņa stāsta, kā procesiju vērošana (dievietes statuju iegremdēšana ūden̄̄ svētku beigās) viņai l̦āvusi dziedināties un "atlaist mirušo dvēseles": "Mēs visi pārkāpjam savām bailēm un dēmoniem. [..] Es esmu runājusi ar Kālī naktī. [..] Es redzu, kas ir viñas mācība. [..] Es esmu pieredzējusi šo izšķı̄šanu ar svētcel̦niekiem Babu Ghatā. Sēru ritualizāciju. Tūkstošiem cilvēku ar savām īpašajām Kālī (figūriñām), iespējams, jūtoties līdzīgi kā es. [..] Es aizmetu savu tuvinieku dvēseles prom. Kā Kālī Kalkutā [Kalkātā], tās iegrimst Gangā. Es atlaižu savas ciešanas [..] es pati pieredzēju izšǩīšanu." ${ }_{56}$

Līdzīgā veidā Nika Kučuka savā doktora darbā intervē vairākas sievietes, kas spontāni, bez pašu apzinātas gribas (vienai no tām, piem., pārstāvot islāmticību) piedzīvojušas Kālī vīzijas un palīdzību dzìves krīzes momentos. Viena no viņām saka: "Es domāju, ka viņa nāk laikos, kad tu esi gatavs, lai Viņa nāk, pat ja mums tas nepatīk. Viņa ir klāt, kad tu esi klāt, kad viņa sauc; dažkārt tas prasa laiku, lai sajustos

${ }_{55}$ Šāda interpretācija nav nekāds jaunums arī senākos laikos. Tā, piemēram, kādā 13. gs. Sinhala budisma tekstā Saddharmaratnāvaliya, kas stāsta veidā izklāsta budistu ētiku, parādās dēmone Kālī. Ranjini Obeyesekere and Gananath Obeyesekere, "The Tale of the Demoness Kālī: A Discourse on Evil,” History of Religions, 29:4 (May 1990), 318.

${ }_{56}$ Lloyd, op. cit., 58-59. 
pietiekami spēcīgs un sekotu aicinājumam [... un tā es teiktu krīzes situācijās, [..] mirkḷos, kad nepieciešams "grūdiens"." ${ }_{57}$ Intervētās sievietes apraksta Kālī pieredzi kā negaidīti aizsargājošu un transformējošu - dieviete viņas aicinājusi pārvarēt bailes un virzīties dzīvē tālāk. ${ }^{58}$ Ironiski, ka, viņuprāt, tieši šausminošās, iznīcinošās dievietes, kā Kālī, rada drošu telpu, kur visas patības daḷas var tikt pieņemtas: "[..] skatīties tieši sejā dievišķajam ir biedējoši. Konfrontēties ar sevi, skatīties uz saviem ievainojumiem, sāpēm ir baisi. Izaicināt sevi augt ir bailīgi. Un tieši tādēḷ es domāju, ka tās dievības izskatās tik šausminošas. Viņas nav sliktas, l̦aunprātīgas, bet iegūst daudz negatīvu projekciju, jo cilvēki nevēlas tās redzēt, viņi nevēlas strādāt ar "sliktajām lietām"."

\section{Kālī un feminisms}

Kaut gan hinduisms ir bagāts ar sieviškso dievību klāstu, kas ir plaši pielūgtas tautas masās, ar dažādiem "sievišksiem" metafiziskiem jēdzieniem (maya, prakriti, avidjā, šakti) ${ }^{60}$, ar tādām kustībām kā šaktisms un tantrisms, kas Dieva sievišķo aspektu pacel augstākā principa statusā, kā arī uzskata, ka katra sieviete ir Lielās Dievietes iemiesojums jeb vienā vārdā tas, ko Kālī pielūdzēja un pētniece Nīla Batačarja Saksena (Neela Bhattacharya Saxena) nosaukusi par hinduisma "ginocentrisko matricu", ${ }^{61}$ tomēr savdabīgā kārtā šim fenomenam nav nekādu pozitīvu implikāciju attiecībā uz reālu sieviešu

${ }_{57}$ Kuchuk, op. cit., 174.

58 Ibid., 179 u. c.

59 Ibid., 182.

60 Šis aspekts gan vēl nenozīmē, ka tam ir pozitīvas implikācijas, jo nereti šie jēdzieni tikuši interpretēti, degradējot sieviškso/sievieti. Piemēram, ka sieviete bez vīra (jeb apziņas/Sivas) vadības analogi sieviškajiem principiem ir tikai nesaprātīga potencialitāte (šakti), "ilūziju vērpēja" (mājō), nezināšana (avidja) utt. To, kā var šos jēdzienus interpretēt citādāk, skat., piemēram, Gupta, op. cit., 25-29.

${ }_{61}$ Ar "ginocentrisko matricu" vai zemapzinātu struktūru, kas ir pamatā indiešu domai un kultūrai, Saksena domā tieši šos sievišksos konceptus (maija, prakriti, šakti), kas ir neatņemama hindu domas sastāvdaḷa. Viņa redz Kālī kā "Ginocentrisko universu, saaustu matricu, kas atzīst sieviškso ar tādu spēku, ka nekāda patriarhāla apspiešana nav spējusi to iznīcināt [..]”. Kuchuk, op. cit., 57, 153. 
ikdienas dzīvi. ${ }^{62}$ Hindu feministe un pētniece Lina Gupta apraksta savas bērnības pieredzi ar dievietes Kālī ikdienas godināšanu, novērojot šo savdabīgo neatbilstību, - dievietes iedvesmojošais piemērs pretstatā ierobežojošajām normām, kam jāpakḷaujas vidusmēra meitenei un sievietei. ${ }^{63}$

Feminisma aktivitātes saistītas galvenokārt tieši ar šo aspektu - patriarhālo sociālo organizācijas formu dekonstruēšanu, jo gan kristiešu, ${ }^{64}$ gan musulmaņu, ${ }^{65}$ gan hindu ${ }^{66}$ un budis$t^{67}$ feministes nereti vienā balsī norāda, ka pašas šīs tradīcijas nav patriarhālas, to kodols ir egalitārs, problēmas rada cilvēciskās normas un struktūras, kas tās atbalsta. Tā, apmēram

${ }_{62}$ Ja kādai sievietei izdodas sasniegt augstu pozīciju "garīgajā jomā" kā, piemēram, Ānandamaȳ $M \bar{a}$, tad tiek uzskatīts, ka viņa transcendējusi dzimumu pilnībā (Rachel Fell McDermott, "Goddess Worship: the Hindu Goddess," in Encyclopedia of Religion, op. cit., 3609.

63 Gupta, op. cit., 16-17.

${ }_{64}$ Šeit varētu minēt daudzus, bet, piemēram, Ronalds V. Pīrss (Ronald W. Pierce), Rebecca Merrill Groothuis un Gordons D. Fī (Gordon D. Fee) publicējuši grāmatu "Atklājot biblisko vienlīdzību: komplementaritāte bez hierarhijas" (Discovering Biblical Equality: Complementarity without Hierarchy). Danielle S. Dela George, The Evangelical Gender Dilemma: from Traditionalism to Feminism and the Spaces in Between: A capstone submitted to the Graduate School-Camden Rutgers, The State University of New Jersey in partial fulfillment of the requirements for the degree of Master of Arts in Liberal Studies Graduate Program in Liberal Studies written under the direction of Dr. Stuart Charme (Camden, New Jersey, 2014), 12.

65 Musulmaņu feministe Rifata Hasana (Riffat Hassan) pat uzskata, ka Korāns ir vairāk nekā egalitārs, jo īpaši liekot akcentu uz mazākspējīgo, tostarp sieviešu, atbalstu. Riffat Hassan, "Muslim Women and Post-Patriarchal Islam," After Patriarchy: Feminist Transformations of the World Religions, P. M. Cooey, William R. Eakin and Jay B. McDaniel, ed. (Orbis Books, Maryknoll), 59.

${ }_{66}$ Lina Gupta saka: “[..] hinduisms savā būtībā nav patriarhāls.” Runājot par dievieti Kālī: "Tiekot pie dzil̄ākās dievietes nozīmes, mēs tuvojamies daudz pilnīgākai rakstītā hinduisma būtības izpratnei.” Gupta, op. cit., 16.

${ }^{67}$ Budistu feministe Rita Gross saka: "[..] ir jāatrod budisma kodols, kas jau ir pāri patriarhijai." Rita M. Gross, "Buddhism after Patriarchy?," Religion and Social Transformation, ed. David Herbert (Ashgate, 2001), 66. "Manās iepriekšējās budisma feministiskajās analīzēs es esmu pārstāvējusi viedokli, ka pamata budistu mācības nav mizogīniskas vai patriarhālas; es esmu arī demonstrējusi, ka budisma bāzes doktrīnas, kā tās šobrīd tiek pasniegtas, nekādā veidā neatbalsta dzimumu hierarhiju un patiesībā pat vēršas pret šādām praksēm.” Ibid., 70. 
sākot ar 3. gs. BC, ${ }^{68}$ Indijā tiek ieviesti t. s. Manu likumi (jeb Darmašastra), kas stingri reglamentē sievietes dzīvi. Sieviete nav spējīga uz patstāvīgu eksistenci, tai vienmēr jābūt kāda vīrieša uzraudzītai, kā arī sieviete ir neprognozējama būtne, kas atrodas savu dzin̄u varā un kas pastāvīgi jākontrolē. ${ }^{69}$ Manu likumi vēl joprojām tiek uzskatīti par hindu sociālās dzìves pamatu, kaut gan daudzas to normas ir novecojušas.

Patriarhālā sociālā struktūra ietekmē arī religiskos tēlus. Lielākā daḷa hindu dieviešu pārstāv šajā iekārtā vēlamo sievietes ideāltipu, būdamas maigas, paklausīgas sievas saviem vīriem. ${ }^{70}$ Kaut gan tāda dieviete kā Kālī ir daudz grūtāk ievietojama šādā paraugā, tiek uzskatīts, ka arī viņa "cieš" no patriarhālām interpretācijām, atspogulıojot vīriešu bailes no neiegrožota sievišksā spēka. ${ }^{71}$ Gan ikdienā, gan arī īpaši psihoanalītiskās interpretācijās sastopams šāds Kālī vērtējums tā ir sievišksā histērija un destruktīvais potenciāls, kas jāsavalda (un mītos to parasti izdara vīrišksais dievs Šiva). ${ }^{72}$ Tiek uzskatīts, ka šādi mīti norāda uz vēsturiski pastāvējušo spriedzi starp šivistiem un Kālī pielūdzējiem, kur, l̦oti iespējams,

${ }_{68}$ Lina Gupta savā rakstā Kali, the Saviour norāda 7. gs. BC kā šo normu sākumu, bet tā ir neprecizitāte, jo hindu likumi sastāv no Darmasutrām, kas ir senākas (600/300 BC - $400 \mathrm{CE})$, un Darmašastras, no kurām svarīgākā daḷa ir Manava Dharmasastra jeb Manu likumi, kas datējami ar 200 BC lìdz 100 CE. Alf Hiltebeitel, "Hinduism," in McMillan Compendium "World Religions": Single-Volume Encyclopedia (Mcmillan Library Reference USA, 1998), 490.

69 Gupta, op. cit., 17-20.

70 Piemēram, Sìtā, Pārvatī utt. Tomēr ne tikai Kālī ir paradokss šajā ziñā, jo arī dieviete Radhā nav nekāds paraugs, jo uzskatāma par laulības pārkāpēju. Rachel Fell McDermott, "Goddess Worship: the Hindu Goddess,” in Encyclopedia of Religion, op. cit., 3609.

${ }_{71}$ Tā esot, piemēram, Badrakālī kultā, ko veido gandrīz tikai vīrieši. Ibid. Šeit varētu atsaukties arī, piemēram, uz amazoņu atainojumu 19. gs. literatūrā, kurš ticis domāts nevis kā sieviešu spēka un patstāvības demonstrējums, bet gan tieši, lai parādītu, kāds neprāts un haoss iestājas, ja sievietes "tiek pie varas". Cynthia Eller, Gentlemen and Amazons: The Myth of Matriarchal Prehistory, 1861-1900 (Berkeley: University of California Press, 2011), 17.

${ }^{72}$ Purāniskajos mìtos Kālī, uzveicot dēmonus un dzerot to asinis, nereti tiek pārņemta ar neprātu, kas apdraud pasaules kārtību, un Šiva viņu aptur, tēlojot vai nu līksi, vai bezpalīdzīgu zīdaini utt. 
pirmie radījuši mītus, kur Šiva vienmēr uzvar Kālī, ${ }^{73}$ turklāt dieviete "aiz kauna iekož sev mēlē" " vai zaudē Šivam deju sacīkstēs, jo neiedrošinās izpildīt "nepiedienīgo" pozu, kad Šiva pacel̦ kāju vertikāli virs galvas (tā dēvētais Urdhva Tandava deju solis). ${ }^{75}$

Pie patriarhāliem "izkroplojumiem”, iespējams, pieder arī Vamana Purānas mīts, kur dievieti Pārvatī tās melnās sejas dēḷ Šiva nosauc par Kālī jeb melno, viņa sadusmojas un ar lielām pūlēm iegūst sev baltu seju, melnajai kḷūstot par atsevišksu dievību. ${ }^{76}$ Tāpat ir mīti, kur niknā dieviete nereti parādās kā

${ }^{73}$ Pētnieks D. Kinslijs (D. Kinsley) norāda, ka šāda tendence uzrāda spriedzi starp šaivisma tradīciju un Kālī pielūgsmi (gan kā senu lokālu dievību, gan viņas kulta izplatīšanos). David Kinsley, "Freedom from Death in the Worship of Kālī,” Numen, Vol. XXVI, Fasc. 3, 193-195.

${ }_{74}$ Šis jautājums ir veselas diskusijas vērts, jo Kālī iekošana mēlē "aiz kauna" ir Orisā izplatīta interpretācija, ko citēs katrs vietējais, tomēr pētnieks Džefrijs Kripals (Jeffrey Kripal) norāda, ka jautājums nebūt nav tik viennozīmīgs. Pirmkārt jau, lai iekostu mēlē, tā nav jāizbāž pāri zodam! Dažkārt pat tiek norādīts, ka Kālī mēle var būt 9 jūdzes gara. Kripals norāda, ka Kālī mēles interpretācija ir saistāma drīzāk ar tantrisko tradīciju (visa nepatīkamā sevī intīmu pieņemšanu) un tās tulkojums kā "aiz kauna" norāda uz spriedzi bengāḷu kultūrā starp tantrisko un ortodoksālo tradīciju. Katrā ziņā, tāpat kā ar deju soli, kas tiks aplūkots nākamajā atsaucē, ir ārkārtīgi paradoksāli, ka niknā, bezbailīgā dieviete Kālī bikli nokaunas par "uzkāpšanu savam vīram”, un tā ir klaji patriarhāla interpretācija (to nesaka Kripals, bet es pati), jo hindu sievietes, protams, nekad neko tādu nedrīkstētu atḷauties. Jeffrey J. Kripal, "Kālī's Tongue and Ramakrishna: "Biting the Tongue" of the Tantric Tradition," History of Religions, 34:2 (Nov. 1994), 153-155.

${ }_{75}$ Tà esot sena tamilu legenda, kas saistīta ar cīņu par Čidambaramas un Tiruvalankatu templa pārvaldību 14.-15. gs. Š̉iva uzvar šajās sacīkstēs, un Kālī tiek padzīta no pilsētas. Šis mìts tik tiešām ir vēlāks, acīmredzami patriarhāls darinājums, jo pētnieki norāda, ka Urdhva Tandava poza sākotnēji nav saistīta ar dievieti Kālī, šì konotācija tiek "piedzejota" vēlāk. Turklāt niknā, spēcīgā Kālī, kas uzveic pat briesmīgākos dēmonus, šeit attēlota kā savdabīgi bikla un paklausīga. Archana Verma, Performance and Culture: Narrative, Image and Enactment in India (Cambridge Scholars Publishing, 2011), 12.

76 Gupta, op. cit., 22. Šādas interpretācijas uzskata par patriarhālām, jo šajā iekārtā ir hierarhisks dalījums, kas skar ne tikai sievietes, bet arī citas "zemākās būtnes". Tiek uzskatīts, ka dievietes Kālī melnā krāsa ir saistāma ar tās izcelsmi kā cilšu auglības dievietei un tās saikni ar zemi, tāpēc var pieņemt, ka dieviete Kālī tikusi uzskatīta par "primitīvo l̦aužu" dievieti. Gan vēsturiski, gan mūsdienās Kālī pielūgsmē vairāk iesaistīti "parastie cilvēki” un intelektuāḷi dievietes godināšanu nereti ìsti pat neatzīst. To norāda Bengālē mūsdienās dzīvojošā jau iepriekš citētā žurnāliste Šoma A. Čatedži (Shoma A. Chatterji): "Viṇa (Kālī) 
paklausīga Šivas sieva un palīdze. Daudzi patriarhālo aizspriedumu garā pat neatzīst Kālī par sievišksu dievību. ${ }^{77}$ Jau minēto iemeslu dēḷ hindu feministes ne pārāk bieži izmanto Kālī un Durgu savās aktivitātēs. ${ }^{78}$ Izñēmums ir sievietes, kas ieņēmušas augstus amatus kā garīgās un politiskās līderes, piemēram, Indira Gandija. ${ }^{79}$ Pat ja dievieti saskatītu kā spēcīgu, neatkarīgu un drosmīgu, kā tas ir, pat skatoties caur patriarhālo prizmu, kādu labumu gan tas var dot vidusmēra sievietei, kas nemaz nelīdzinās šādam tēlam. ${ }^{80}$

Turpretī Rietumu feministes gan smēlušās bagātīgu iedvesmu hindu dievību, tostarp Kālī, tēlos. Tieši pēdējā minētā iemesla (kareivīguma) dēl Kālī bijis izdevīgs jājamzirdziņš niknajām feministēm, jo tās, līdzīgi Kālī, kas nežēlīgi uzveic dēmonus, ir cīnījušās par sieviešu tiesībām. ${ }^{81}$ Tajā pašā laikā

dzīvo vairāk zemāko slāņu vidē, kuri “tikko savelk galus kopā”, pelnot ar ātrajām uzkodām vai taksometra pakalpojumiem. Viņa nav tik redzama starp intelektuāḷiem un elitārām institūcijām.” Shoma A. Chatterji, "The "Culture" of Kali - the Secular Goddess," op. cit. Tāpat jau iepriekš norādīts, ka tādas prominentas personas kā Rabindranats Tagore un citi ir kritizējuši Kālī kultu. David Kinsley, "Freedom from Death in the Worship of Kālī,” op. cit., 205.

77 Ivbulis, op. cit., 285-286.

${ }_{78}$ Rachel Fell McDermott, "Goddess Worship: the Hindu Goddess," in Encyclopedia of Religion, op. cit., 3609.

${ }_{79}$ Rachel Fell McDermott, "Durgā and Kālī," in Encyclopedia of Women and World Religion, op. cit., 275.

${ }^{80}$ V. Ivbulis pat izsaka domu, ka šāds dievību prominents statuss, iespējams, kompensē vidusmēra sievietes apspiesto stāvokli. Ivbulis, op. cit., 279. Arī hindu feministe Vrinda Dalmija norāda, ka hinduismā eksistē šāda ideja. Vrinda Dalmiya, "Loving Paradoxes: A Feminist Reclamation of the Goddess Kali,” Hypatia, 15:1 (Winter, 2000), 128. Turklāt viñš pieder pie tiem, kas Kālī, Durgu un citas kareivīgās dievietes neuzskata par sievišk̉īgām: "Hinduismā līdz ar vīriešu kārtas dieviem tiek pielūgtas arī sievišksās dievības, kuras gan bieži vien nav sievišksīgas. [..] Kālī Purānas izcel̦as ar to, ka tā neko nedara kā sieva vai māte, bet stājas vīrišķ dievu vietā kā cīnītāja kaujas laukā. [..] Tādā veidā Durga it kā ir daļa no vīrišksajiem [..] augstākajiem un zemākajiem dieviem. [..] Tā kā viņa nav arī îsti sievišksa būtne, Indijas feminisma kustības dalībnieces, būdamas ḷoti racionāli un mūsdienīgi domājošas sievietes, Durga neñem sev palīgā. Bet varbūt ir tā: Durga ir tik varena un tik iespaidīgā veidā pielūgta, ka tai zudis jebkāds sakars ar sievieti. Arī viņai veltītos svētkus, jau krietni iepriekš izspiezdami naudu no katra, kas var un nevar atlauties [..] rīko vīrieši.” Ivbulis, op. cit., 279-285.

81 Nika Kučuka norāda uz daudziem iemesliem, kamdēḷ Kālī ir bijis nepieciešams tēls šajā procesā - piemēram, uz to, ka Rietumu kultūrā trūkst šādu veselīgu sievišķa, produktīva niknuma paraugu un ka 
Kālī kā feminisma (atbrīvošanās vispār) simbols ir saredzama vēl vismaz divos veidos - viens ir tas, ka šaktisma simbolika ar tās realitāti pieņemošo, neduālo redzējumu ir atbrīvojoša, Indijā dieviete ir nepārspējami egalitāra ar to, ka pieņem pilnīgi visus, - gan noziedzniekus, gan svētos, ${ }^{82}$ bet Kālī iekḷaujošās dabas "izplešanās uz Rietumiem” piemērs ir mistiķis Ramakrišna un vēlāk Vivekanandas dibinātā Ramakrišnas Misija, kas universālās mātes Kālī garā saskatīja, ka visas ticības ved uz vienu mērķi, un radīja šādu visaptveroši pieņemošu paradigmu. ${ }^{83}$ Šajā kontekstā varētu pat apstiprināt bieži piel̦auto pārpratumu, ka Kali juga ir dievietes Kālī laikmets. ${ }^{84}$ Otrkārt, feministes saskata Kālī kā atbrīvošanās simbolu tās tantriskajā izpratnē. Hindu pētniece Lina Gupta savā esejā "Pestītāja Kālī" (Kali, the Saviour) norāda, ka tantriskais ir dzil̄ākais izpratnes līmenis, kas var arī visvairāk kalpot

dusmīga sieviete vēl joprojām tiek uzskatīta par histērisku, iracionālu utt. "Līdz ar to nav pārsteigums, ka Kālī tēls, nikna sieviete, kas vienlaikus ir dievišksa, ir tik iedarbīgs uz garīgi noskaņotajām feministēm.” Kuchuk, op. cit., 124. Šeit gan jāmin, ka tas nav tikai Rietumu feministu gadījums, arī pašā Indijā, protestējot pret britu koloniālismu, daudzi nacionālisti izmantoja tantrisko asinskāro dieviešu tēlus, lai demonstrētu sacelšanos pret "baltajiem koloniālistiem”. Rachel Fell McDermott, "Goddess Worship: the Hindu Goddess," in Encyclopedia of Religion, op. cit., 3609 .

82 Kā izsakās žurnāliste Šoma A. Čaterdže: "Viņa $(K \bar{a} l \bar{\imath})$ ir, iespējams, vienīgā neitrālā (value-neutral) dievība hindu panteonā, ko tikpat dedzīgi pielūdz gan noziedznieks, gan vienkārša mājkalpotāja, uzṇēmējs un ubags uz ielas, spitālīgais un invalīds, mirstošie un visu zaudējušie. Šajā ziņā viņa sevi parāda kā demokrātiska Dieviete Māte, kas nešķiro savus pielūdzējus, balstoties uz sociālajām struktūrām vai morālajiem standartiem, ko radījusi cilvēce kā tāda.” Shoma A. Chaterjee, op cit. Arī hindu feministe Vrinda Dalmija saskata Kālī atbrīvojošo potenciālu tieši bhakti jeb dievietes pielūgsmes kontekstā, jo, pielūdzot dievieti, jāizrāda cieņa pret to, ko viña pārstāv (piem., dabu), kā arī bhakti pielūdzējs attiecībā pret dievieti îr kā bērns vai kā sieviete, atmetot "kunga attieksmi" utt. Dalmiya, "Loving Paradoxes: A Feminist Reclamation of the Goddess Kali," op. cit., 125-150.

83 "Our Mission," Kali Mandir: Ramakrishna Ashram, www.kalimandir. org (skatīts 10.05.2018.)

${ }^{84}$ Parasti tiek norādīts, ka tā ir intelektuāla kḷūda un vārdam Kali jugas kontekstā ir cita sakne nekā dievietei Kālī (Kuchuk, op. cit., 134-135), tomēr savā ziṇā dieviete ir tā, kas uzveic dēmonus, kuri "pagrimuma laikmetā" zeḷ pilnā sparā, kā arī ar savu egalitārismu acīmredzot iedvesmo dažādu veidu atbrīvošanās kustības. 
vispārējai atbrīvojošai praksei. ${ }^{85}$ Tantrismā dieviete Kālī tiek uzskatīta par Augstāko Realitāti, pašu Brahmanu, kas ietver visas potencialitātes. Gupta parāda Kālī simboliku kā atsvabinošu - dieviete ir kaila un nav greznojusies ar dārgakmeņiem kā citas dievietes, jo viņa nepakl̦aujas sociālām normām par sievišksību, ${ }^{86}$ Guptas vārdiem, viņa iemieso sieviešu kolektīvo niknumu, sastopoties ar netaisnību. Kālī rīcība ir ārpus sievišk̉ā-vīrišķ̄ā dualitātes, tāpat viņas biedrošanās ar zemākajām kastām un nešks̄istajiem dzīvniekiem norāda uz to, ka viņa transcendē jebkādas ierobežojošas un diskriminējošas prakses. ${ }^{87}$

Noslēgumā gan jāteic, ka tantrisma celšana feminisma slavas saulītē arī ir neviennozīmīga. Interesanti, ka pašā tantrismā šādas konotācijas nav, jo tantrisms ir vērsts uz personisku atbrīvošanos no šīs pasaules ierobežojumiem, ${ }^{88}$ tādēḷ tam īpaši nerūp sociālais taisnīgums un vienkāršās sievietes statuss. Tantrists, šķiet, tik l̦oti vēlas brīvību, ka labāk atbrīvo sevi, nevis sociumu, ${ }^{89}$ galu galā tantrisma mērksis ir individuāla, nevis kolektīva atbrīve, tāpēc tā simbolismu "normālā" kontekstā var

${ }_{85}$ Gupta, op. cit., 16-17.

86 Ibid., 23-24.

87 Ibid., 31-33.

88 Šeit gan jāpiemin, ka tantras cel̦š, atšksirībā no jogas u. c., runā par apskaidrības sasniegšanu "pasaules vidū”, t. i., saglabājot ķ่ermeni (īpaši tādēl, ka k̉ermenis tiek izmantots kā atbrīvošanās instruments). Ar atbrīvošanos "no pasaules likstām” domāta nevis materiālā realitāte kā tāda, bet gan sociālā ilūzija, jo tantrists ir apveltīts ar dažādām īpašām spējam, tostarp nemirstību, tāpēc to diez vai satrauktu tas, kas parasto cilvēku. Protams, var būt, ka tantras "pamatsoḷi" ir adaptējami arī vispārēji atbrīvojošai praksei (ja jau to tik ļoti iecienījuši Rietumu aktīvisti). Arī tantriskā budisma pārstāve feministe Rita Gross uzskata, ka šis budisma veids ietver sociālu iesaisti (viņa runā par "brīvība pasaulē" vs "brīvība no pasaules" paradigmām - cilvēks, kas ir patiesi brīvs, ir brīvs arī savās ikdienas gaitās (darbā, ğimenē utt.)), tātad neizbēgami šāda veida prakse radīs arī sociālas izmaiņas (Rita M. Gross, "Buddhism after Patriarchy?," op. cit., 65-85), par mūsdienu neotantristiem nemaz nerunājot (tas tiks aplūkots tālāk), - viņuprāt, tantra nozīmē vispārēju dzīves kvalitātes uzlabošanu, visa vienotības apzināšanos, asākas, dzīvākas maņu izjūtas, lielāku intimitāti starp cilvēkiem utt. Tas, cik tas ir vai nav oriğināli tantriski, ir diskutējams jautājums, tomēr domāju, ka tas ir tālu no sākotnējās tantras.

89 Mūsdienu tantristi gan tam varbūt nepiekristu, bet, manuprāt, doma par sociuma pārveidošanu nāk no kristietības, kur pestīšana ir kolektīvs notikums un garīgā attīstība ir saistīta ar "kalpošanu tuvākajam" utt. 
izmantot tikai dal̦ēji. Vēl jo vairāk - tantrisms tiek uzskatīts par marginālu kustību hinduismā, tādēḷ tā filozofija nav īsti saistoša vidusmēra hinduistam. Tantra patiesi ir paradoksāla ar sievišksā elementa pielūgsmi un egalitāro attieksmi tās rituālos, vienlaikus tā tomēr galvenokārt ir "vīriešorientēta" (tās adepti un skolotāji pārsvarā ir vīrieši), ${ }^{90}$ turklāt pat tikusi kritizēta tantras diskriminējošā attieksme pret sievietēm, izmantojot tās kā līdzekli apskaidrības sasniegšanai. ${ }^{91}$

\section{Kālī, neopagānisms un Dievietes kults}

Vēl kāds īpašs Kālī adaptācijas veids Rietumos saistīts ar šeit atkal atdzimstošām pagānisma un dievietes relig̣ijas kustībām. Pagānisma saknes Rietumos ir dziḷas, un, kaut gan kristietība daudz darījusi, lai šo "sakni" izravētu, tomēr arī 20./21. gs. tas turpina dzīt jaunus asnus. Termins "neopagānisms" aptver daudzas dažādas kustības, starp kurām var izškirirt četras galvenās kategorijas: atjaunotu ķeltu druīdu un raganu/buršanas jeb vikas (wicca un witchcraft) tradīcijas, ceremoniālo maǵiju un neošamanismu. Kaut gan neopagānisma piekritēji uzskata, ka ir senu tradīciju mantinieki, tomēr tiek apgalvots, ka lielākoties tās ir jaunradītas, turklāt eklektiskas kustības. Amerikāṇu, kanādiešu, britu un austrāliešu neopagāniem raksturīga feministu un vides aizstāvju kustību ietekme, turklāt šīs grupas tiek veidotas kā egalitāras un individuālistiskas. Kaut gan daudzi neopagāni vēl joprojām pulcējas biedrībās (coven, burtiski "raganu sabats"), mūsdienās, pastāvot lielai informācijas bagātībai, eksistē arī daudzi individuālie praktizētāji jeb, piemēram, "pašdarinātās raganas" (self-made witches) (iepretī senākām tradīcijām, kur bija daudzas iniciācijas pakāpes). ${ }^{92}$

${ }_{90}$ Rachel Fell McDermott, "Goddess Worship: the Hindu Goddess," in Encyclopedia of Religion, op. cit., 3609.

${ }_{91}$ Šis jautājums gan ir kontroversāls un, iespējams, ir saistīts nevis ar autentisko tantru, bet gan ar "šarlatānismu". Kuchuk, op. cit., 65. Tomēr var būt, ka šādu konotāciju radījis fakts, ka adepts var rituālā "izmantot" arī neiesvētītu sievieti, bet, cik noprotams (tas gan esot krietni retāk), tas var būt arī vīrietis, ja adepte ir sieviete. Feuerstein, Tantra: The Path of Ecstasy, op. cit., 243.

${ }_{92}$ Sarah Pike, "Neopaganism," Encyclopedia of Religion, ed. Lindsay Jones, Vol. 10, 2nd ed. (USA: Thompson \& Gale, 2005), 6470-6471. 
Neopagānisma uzplaukums saistāms gan ar kristietības pozīciju vājināšanos 19. gs., gan tātad ar feminisma un vides aizsardzības kustību, kas vērš uzmanību uz cilvēka un dabas mijiedarbību, atrodot senākās dabas religijāās paraugu šādu attiecību harmonijai. Tāpat arī tiek uzskatīts, ka senajās reliğijās daudz lielāka nozīme bijusi sievietei vai vismaz tam, ka vīrieša dominante vēsturiski ir saistāma arī ar dabas postīšanu. Svarīgs aspekts ir neopagānismā bieži populārais panteisms, kas, iepretī patriarhālajam monoteismam, padara planētu par sakrālu esamību, kā arī cilvēka attiecības ar to par tikpat svētām. Neopagānisma ietvaros var pastāvēt arī Dievietes monoteisms vai vienlīdz var tikt pielūgti gan dievs, gan dieviete (tas raksturīgi t. s. gardnera raganām). Mūsdienās vikas kustības sekotāji, kā jau minēts, ir eklektiski noskaņoti un brīvi izvēlas iedvesmas avotus no dažādām reliǵijām, veidojot paši savus rituālus. ${ }^{93}$

Hindu dievības ir l̦oti atbilstošas neopagānu domāšanai, jo arī šaktismā valda doma, ka visa pasaule ir dievišksās Šakti iemesojums, pasaule ir "apdvēsel̦ota". Arī dieviete Kālī ir bagātīgs iedvesmas avots mūsdienu raganām. Viņas vārds pat ticis integrēts vispārējā vikas lūgšanā (jeb Dievietes Mantrā vai Raganu Mantrā), ${ }^{94}$ tāpat Kālī iekḷauta arī dieviešu Taro kāršu komplektos. ${ }^{95}$ Tiek norādīts, ka bieži vien Kālī tiek izmantota neopagānu vidē, pilnīgi neko nezinot par viņas sākotnējo kontekstu, tomēr ir arī konstruktīvāki lietojuma gadījumi. Pētniece Nika Kučuka savu doktora tēzi lielā mērā veltījusi tieši šādai eklektiskai kustībai ar nosaukumu "Šakan" (Sha'can no Šakti un wiccan).

"Šakan” līdere ir Čandra Aleksandra - ne vien Indijā iesvaidīta tantras mistērijās, bet arī ar akadēmisku, teologíisku izglītību, ${ }^{96}$ tāpēc viñas veiktā sintēze ir apzināta, iedziḷinoties

93 Sarah Pike, "Neopaganism," Encyclopedia of Religion, ed. Lindsay Jones, Vol. 10, 2nd ed. (USA: Thompson \& Gale, 2005), 6470-6471.

${ }_{94}$ Š̀̃ mantra skan: "Izīda, Aštarte, Diāna, Hekate, Dēmetra, Kālī, Inanna”, katrai no dievietēm reprezentējot atšksirīgu dievišksā sievišksā aspektu. Kuchuk, op. cit., 109.

95 Kuchuk, op. cit., 134.

96 Ibid., 20. 
lietas būtībā. ${ }^{97}$ Kučuka apraksta kādu rituālu, ko viņa apmeklējusi. Autentiski hindu elementi ir dievietes Kālī attēls, mantru skaitīšana, ziedošana dievietei, prasādas baudīšana utt., bet neopagāniskie elementi - rituāls notiek aplī, tiek svētīti "četri stūri", piesaukti senči un gari, rituāla beigās tiek izvilkta Taro kārts katram dalībniekam, lai noskaidrotu dievietes vēstījumu. ${ }^{98}$ Tāpat kā citās neopagānisma (un mūsdienu religiozitātes vispār) kustībās, liels uzsvars ir uz dzīvu reliǵisko pieredzi, intimitāti ar dievību/-ām. ${ }^{99}$ No vikas pārņemta arī "mag̣iskās iedarbības" domāšana - ar dievieti "tiek strādāts" praktisku problēmu risināšanai. ${ }^{100}$ Lìdzīgi citām neopagānisma kustībām, Aleksandra liek uzsvaru uz ekolog̣iskiem un sieviešu tiesību jautājumiem. ${ }^{101}$

\section{Nobeigums}

Kālī patiesi ir noslēpumiem apvìta hindu dieviete, kas pat spēj izcelties uz jau tā bagāto un komplekso hinduisma elementu fona. Skaidrs ir tas, ka pat pašā hinduismā Kālī ir pretrunīgi vērtējama dieviete - to plaši godā tautas masas un vienlaikus Kālī pielūgsmei ir arī savi kritiķi no intelektuāḷu vides. Kālī ir "dzīvs paradokss" - reizē viena no visšausminošākajām dievietēm hindu panteonāa, ${ }^{102}$ no otras puses, visus pieņemošā, mīlošā Māte, kas nesavtīgi palīdz saviem sekotājiem. Acīmredzams ir arī tas, ka hinduismā nav nedz vienas Kālī (jo ir dažādas tās versijas ar izmainītiem vārdiem un atribūtiem), nedz vienotas Kālī izpratnes. Kālī var godāt gan vienkāršs hindu ticīgais savā mājas altārī, gan ar neordinārām praksēm

${ }_{97}$ Nereti New Age, neopagānu utt. piekritējiem pārmet, ka tie patvaḹ̄gi sajauc dažādas idejas, bet sastopams arī pretējais viedoklis. Tā Sha’can sekotāji uzsver, ka tieši iedzil̦inājušies teorijā, atšksirībā no daudziem “tradicionālajiem” sekotājiem, kas mehāniski izpilda rituālus. Ibid., 175. Ibid., 15

99 Ibid., 174.

100 Ibid., 104.

101 Ibid., 170.

102 Šeit nevajadzētu aizmirst arī citas šausminošās dievietes, kā Čandikā, Činnamastē, Bhairavī u. c., tomēr būtībā tās var uzskatīt par Kālī vaì Durgas variācijām. 
nodarbinātais tantrists kremācijas laukumā, gan augsti izglītots brahmaņu kārtas intelektuālis, gan pat noziedznieks. ${ }^{103}$

N̦emot vērā tai piemītošo noslēpumainību, interpretāciju daudzveidību un daudzas dievietei piemītošās īpašîbas, Kālī ieguvusi popularitāti arī Rietumos. Kālī iespiedusies Rietumu kultūrā visdažādākajās sfērās, kas nebūt ne vienmēr priecē hindu ticīgos. Noprotams ir tas, ka dieviete Kālī piesaista uzmanību, raisa asociācijas un piel̦auj sava tēla izmantojumu gan tīri komerciāliem nolūkiem popkultūrā, gan cīṇā par taisnīgumu (feminisma u. c. kontekstā), gan sevis izpratnē un transformācijā (Kālī izmantojums psihologijāà). Tāpat dieviete spēj brīvi pievienoties arī dievību panteonam mūsdienu neopagānu kustībās.

Kā sacījusi hindu zinātniece Batačardže, Kālī tik tiešām zināmā mērā revitalizē Rietumu kultūru, rosinot tādas pārdomas, kam vietējā simbolikā īsti nav analoga, jo šeit pārsvarā eksistē vai nu izteikti negatīvi, sātaniski tēli, kas ir "l̦auni" un amorāli, vai arī tiem pretēji - gaiši un labestīgi. Kālī kā tumšā, bet labvēlīgā dieviete ir nebijis precedents, paradokss, kas liek ielūkoties dziļi realitātes noslēpumos. Tāpat tas, ka šī visspēcīgā būtne tiek asociēta ar sievieti, ir vēl viens neparasts elements, kas rosina refleksiju gan Rietumu kultūrā, kura tikko sāk atkopties no patriarhāliem aizspriedumiem, gan pašā Indijā, kur visspēcīgo dieviešu klāstam diemžēl nav bijis pozitīvu seku uz vidusmēra sievietes dzīvi.

\section{Summary}

\section{Goddess Kali in Western Culture - Non-religious Contexts}

The article Goddess Kali in Western Culture - Non-religious Contexts deals with the interpretation of Hindu goddess Kali in the Western hemisphere - in popular culture, psychology, feminism and

${ }_{103}$ Dieviete Kālī tikusi saistīta ar t. s. Thugees kustību - noziedzīgu strāvojumu, kas grupveidā laupījis un nogalinājis. Vienlaikus šī kustība bijusi tāda kā relig̣iska sekta ar saviem guru un iesvētīšanu un izmantojusi Kālī kā savu "patronesi". April Holloway, "Thugees - the Cult Assasins of India", Oct. 2, 2014, Ancient Origins: Reconstructing the Story of $\mathrm{Hu}$ manity's Past, http://www.ancient-origins.net (skatīts 05.05.2018.) 
a little bit in neopaganism, leaving out Kali adaptation in Hindu diaspora and New Age circles for that would take up too much space of this article.

Kali is a very mysterious and varied goddess in Hinduism interpretations of Kali range from personification of a minor, militant goddess' anger in the Puranic literature to a loving Universal Mother in bhakti folk religion and the highest Divinity the Brahman itself in certain tantric circles. The goddess is quite popular in Western hemisphere as well - one could say that Kali is the most recognized Hindu element between people that do not know anything about Hinduism. Her popularity may be connected to her dark, agressive and sexual - in traditionally Christian cultures the forbidden spheres of life-connotations. In Western culture, where we have either evil and dark or benevolent and light entities, goddess Kali is a unique precedent of dark and at the same time benevolent force.

The above-mentioned reasons make Kali a suitable material for popular culture icon (from a decor on T-shirts to a prototype of movie heroes, from a lunch box sticker to a pseudonym of some western porno stars), "strong woman archetype" in feminism, and a variety of symbols in psychology - from "the dark mother" and risks of individuation process in analytical psychology to feminine hysteria and utterly destructive mass forces in psychoanalysis. Kali is attested in individual, spontaneous healing cases as well and also freely joins the neo-pagan "pantheon". 